\title{
Pelatihan Konferensi Interaktif untuk Pembelajaran Jarak Jauh Guru SMP Bina Taruna, Bandung
}

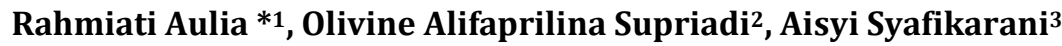 \\ 1,2,3Program Studi Desain Komunikasi Visual, Fakultas Industri Kreatif, Universitas Telkom \\ *e-mail: raulia@telkomuniversity.ac.id ${ }^{1}$, olivinea@telkomuniversity.ac.id ${ }^{2}$, \\ aisyisyafikarani@telkomuniversity.ac.id ${ }^{3}$
}

\begin{abstract}
In the context of a series of training classes for partners that were carried out previously at SMP Bina Taruna Bojongsoang, Bandung, further training will be carried out for teachers to support the learning process. This activity aims to apply knowledge, improve user experience, and introduce online learning media. Improve the ability of teachers to use alternative learning media during the Covid-19 pandemic, especially video conferencing-based media. The activities of this program are carried out by presenting material and practice also direct discussions with the teacher as a participant. The evaluation of this training was $96 \%$ very good and agreed that it was following the goals, interests, and needs of the target community. Respondents expect further training related to the development of previous training.
\end{abstract}

Keywords: teacher, video conferencing, online learning, SMP Bina Taruna

\begin{abstract}
Abstrak
Dalam rangka rangkaian pelatihan terhadap mitra yang dilakukan sebelumnya di SMP Bina Taruna Bojongsoang, Bandung maka melalui kesempatan ini akan dilakukan pelatihan lanjutan pada para guru untuk mendukung proses pembelajaran. Kegiatan ini bertujuan untuk mengaplikasikan keilmuan kepada masyarakat sekitar, meningkatkan pegalaman pengguna dan pengenalan media pembelajaran daring, meningkatkan kemampuan guru dalam penggunaan media pembelajaran alternatif ditengah pandemi Covid19, terutama media berbasis konferensi video. Kegiatan dari program ini dilakukan dengan pemaparan materi dan praktek serta diskusi langsung dengan Guru sebagai peserta. Evaluasi dari pelatihan ini 96\% sangat baik dan sepakat bahwa sesuai dengan tujuan, kepentingan dan kebutuhan masyarakat sasarnya. Partisipan yang merupaka guru SMP Bina Taruna pada kegiatan pelatihan konferensi interaktif ini kedepannya adanya pelatihan lanjutan dengan pengembangan materi dari hasil evaluasi kuesioner.
\end{abstract}

Kata kunci: guru, konferensi video, pembelajaran daring, SMP Bina Taruna

\section{PENDAHULUAN}

Media pembelajaran merupakan sarana dan perangkat yang digunakan dalam mendukung kegiatan proses pendidikan. (Miarso, 2011) mengartikan media pembelajaran sebagai berbagai alat dalam penyampaian pesan yang dapat menstimuli pemikiran, perasaan, perhatian, serta keinginan belajar sehingga dapat membantu dalam proses belajar yang memiliki struktur, tujuan, dan juga kendali. Pergeseran sistem pembelajaran dari konvensional tatap muka ke daring tidak hanya mempengaruhi proses belajar mengajar antara guru dan murid, tapi juga membawa perubahan pada media pembelajaran. Dengan didukung teknologi internet, alternatif media pembelajaran yang dapat digunakan menjadi beragam, salah satunya penggunaan konferensi video.

Berdasarkan fenomena tersebut dan melihat potensi yang dimiliki para guru SMP Bina Taruna untuk dapat membantu meningkatkan kualitas proses pembelajaran (Kemendikbud, 2020; Rosali, 2020; Sadikin \& Hamidah, 2020; Tuti et al., 2020), maka pada kesempatan ini, tim pengabdian masyarakat mengadakan pelatihan konferensi video interaktif dalam mendukung pembelajaran jarak jauh untuk guru SMP Bina Taruna yang diharapkan dapat meningkatkan proses belajar mengajar yang interaktif (Aulia et al., 2021; Sumarlin, 2021) melalui media pembelajaran berbasis konferensi video. Selain itu program Pengabdian Masyarakat ini juga sebagai program lanjutan dari Pengabdian Masyarakat sebelumnya yang sudah memberikan pelatihan kepada para siswa. Pelatihan yang serupa juga telah dilakukan oleh (EDDY et al., 2021; Kemendikbud, 2020; Tampubolon et al., 2021). 
Berdasarkan pengamatan dari pelatihan sebelumnya, guru SMP Bina Taruna kesulitan mencari alternatif media pembelajaran daring yang menarik untuk para siswanya. Dua media pembelajaran utama yang biasa digunakan dalam proses penyampaian materi di SMP Bina Taruna adalah Whatsapp dan layanan konferensi video Zoom. Media konferensi video memungkinkan guru dan para siswa untuk berkomunikasi secara langsung secara daring melalui audio (suara) dan video.

Walaupun media konferensi video yang digunakan dinilai sudah cukup efektif, namun ada masalah yang dihadapi, yaitu proses belajar yang monoton dan cenderung satu arah. Dibutuhkan adanya alternatif konferensi video yang lebih interaktif dan dapat meningkatkan minat belajar siswa SMP Bina Taruna.Melihat fenomena tersebut, isu perihal penggunaan media konferensi video interaktif untuk mendukung proses pembelajaran di SMP Bina Taruna menjadi sangat penting.

\section{METODE}

Kegiatan pelaksanaaan pengabdian pada masyarakat ini terdiri dari tiga dosen dan dua orang mahasiswa Desain Komunikasi Visual, Fakutas Industri Kreatif, Universitas Telkom. Untuk tahapan kegiatannya terbagi menjadi tiga yaitu tahapan persiapan, pelaksanaan dan evaluasi hasil akhir.

1. Tahapan awal, tim pengabdian melakukan persiapan yang meliputi beberapa hal sebagai berikut:
a. Wawancara dan survei mitra pengabdian pada masyarakat;
b. Pembuatan proposal;
c. Penyelesaian administrasi perijinan pengabdian pada masyarakat;
d. Penyusunan materi.

2. Tim melaksanakan kegiatan pengabdian pada masyarakat berupa pelatihan konferensi video interaktif dalam mendukung pembelajaran jarak jauh untuk guru. Setiap guru SMP Bina Taruna, Bojongsoang, Bandung, Jawa Barat mendapatkan materi pengertian konferensi video interaktif dan perannya sebagai media alternatif untuk pembelajaran jarak. Metode yang digunakan adalah ceramah dan diskusi.

3. Simulasi penggunaan aplikasi konferensi, setiap peserta akan diberikan kesempatan menggunakan fitur pada konferensi video interaktif dan berinteraksi pada aplikasi tersebut.

4. Tahap akhir merupakan proses evaluasi kegiatan pelatihan meliputi:

a. Evaluasi kegiatan pelatihan pada akhir sesi pelatihan berupa aktifitas peserta dalam melakukan proses tanya jawab dan diskusi mengenai konferensi video interaktif yang disimulasikan sebelumnya.

b. Pengisian kuisioner, sebagai evaluasi feedback kegiatan serta pengumpulan data mengenai topik apa yang diinginkan dalam pelatihan pada periode selanjutnya dari guru SMP Bina Taruna.

\section{HASIL DAN PEMBAHASAN}

Pelaksanaan kegiatan pengabdian pada masyarakat berupa "Pelatihan Konferensi Video Interaktif dalam Mendukung Pembelajaran Jarak Jauh untuk Guru SMP Bina Taruna, Bojongsoang, Bandung, Jawa Barat" dilakukan pada hari rabu 27 Oktober 2021 bertembat di SMP Bina Taruna berada di Jl. Ciganitri 306, Kelurahan Cipagalo, Kecamatan Bojongsoang, Kabupaten Bandung Jawa Barat. 


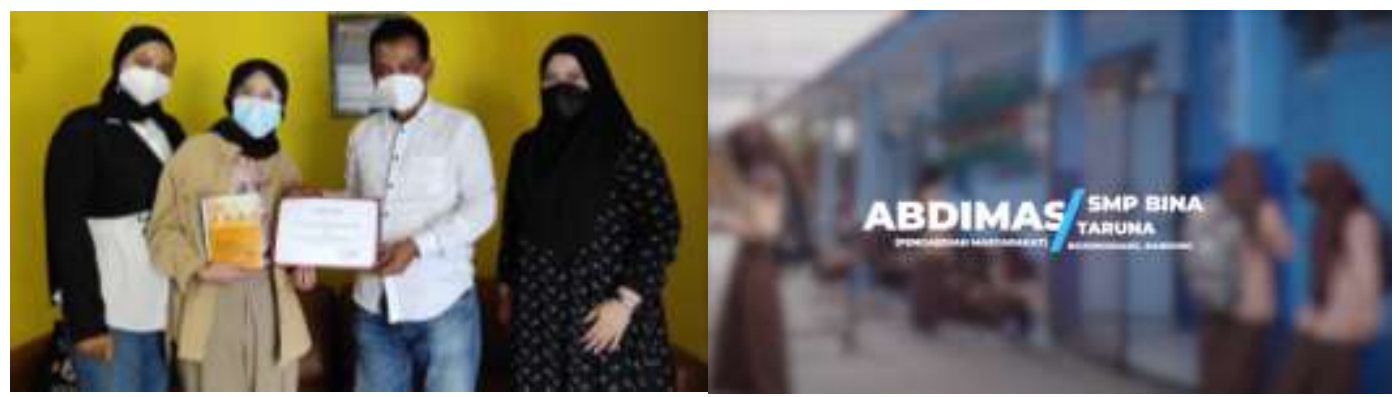

Gambar 1. Penyerahan Hibah (kiri); Dokumentasi YouTube(kanan).

Berdasarkan pengamatan dari pelatihan sebelumnya, guru SMP Bina Taruna kesulitan mencari alternatif media pembelajaran daring yang menarik untuk para siswanya. Dua media pembelajaran utama yang biasa digunakan dalam proses penyampaian materi di SMP Bina Taruna adalah Whatsapp dan layanan konferensi video Zoom. Media konferensi video memungkinkan guru dan para siswa untuk berkomunikasi secara langsung secara daring melalui audio (suara) dan video.

Walaupun media konferensi video yang digunakan dinilai sudah cukup efektif, namun ada masalah yang dihadapi, yaitu proses belajar yang monoton dan cenderung satu arah. Dibutuhkan adanya alternatif konferensi video yang lebih interaktif dan dapat meningkatkan minat belajar siswa SMP Bina Taruna.Melihat fenomena tersebut, isu perihal penggunaan media konferensi video interaktif untuk mendukung proses pembelajaran di SMP Bina Taruna menjadi sangat penting.
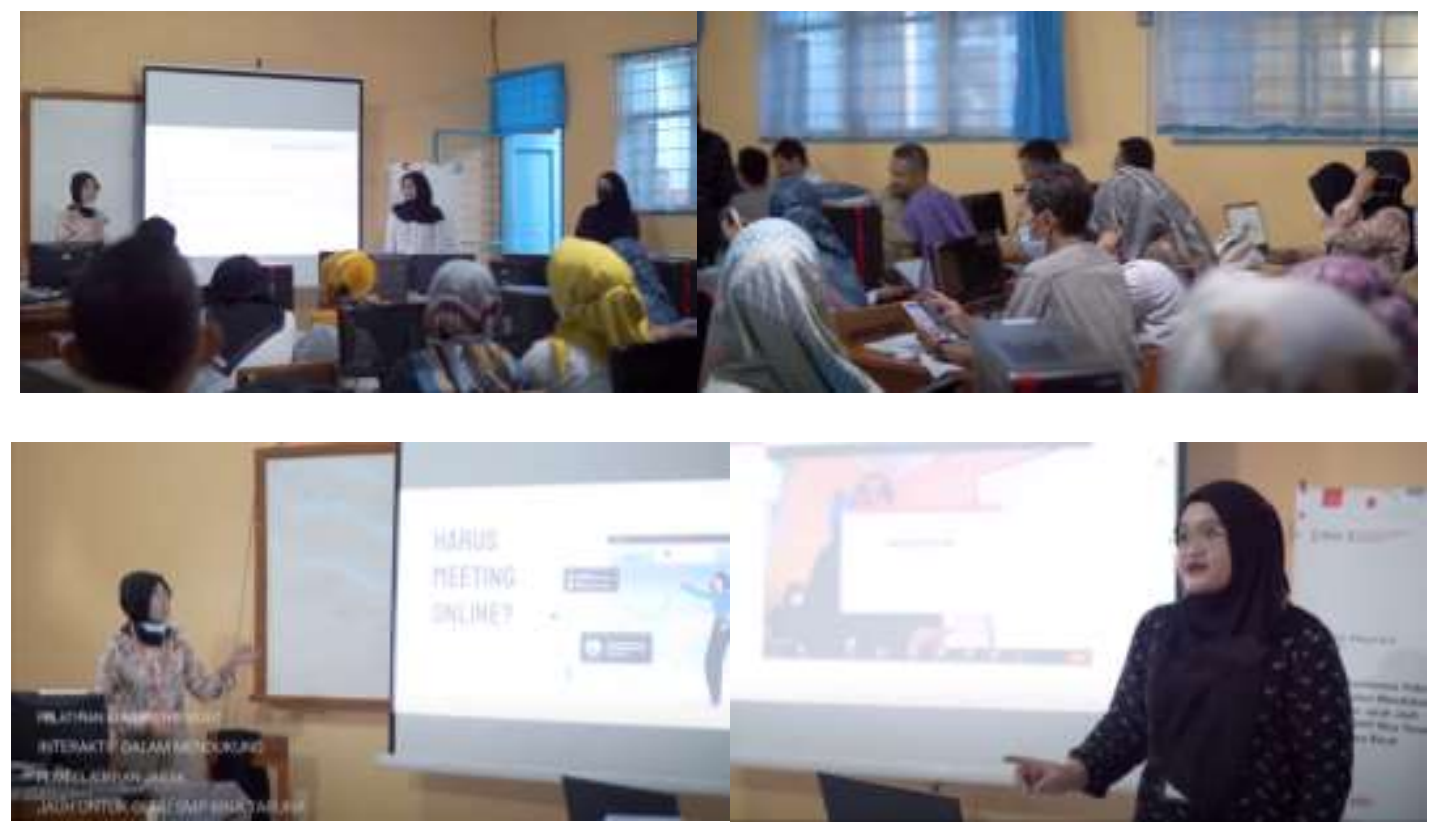

Gambar 2. Pelaksanaan Pelatihan

Beberapa materi yang disampaikan pada pelatihan konferensi video interaktif dalam mendukung pembelajaran antara lain:

1. Mengenalkan media alternatif selain Whatsapp yang dapat digunakan untuk pembelajaran;

2. Mengenalkan apa itu konferensi video interaktif;

3. Menjelaskan perlunya media berbasis video interaktif bagi pelaku SMP Bina Taruna;

4. Menjabarkan beberapa contoh layanan konferensi video interaktif; 
5. Menjelaskan basis penggunaan Zoom sebagai layanan konferensi video interaktif yang paling sering digunakan;

6. Menjelaskan cara mengundang partisipan kedalam ruang virtual Zoom, perbedaan partisipan biasa dan host serta co-host, serta cara mengakhiri ruang virtual;

7. Menjelaskan basis penggunaan Google Meet sebagai layanan konferensi video interaktif berbasis web

8. Menjelaskan cara mengundang partisipan kedalam ruang virtual Google Meet, cara menghubungkan meeting dengan Google Calendar, serta cara mengakhiri ruang virtual

Tingkat keberhasilan pada kegiatan pengabdian masyarakat melalui pelatihan diukur melalui kuesioner yang diberikan kepada peserta pada akhir pelatihan dengan menggunakan skala Likert (Joshi et al., 2015). Penggunaan skala, seperti jawaban: sangat tdk setuju, tidak setuju, setuju dan sangat setuju. Kuesioner dibagikan kepada guru peserta pelatihan dan didapatkan dari 22 peserta pelatihan dengan rekapan hasil feedback seperti pada table berikut.

Tabel 1. Rekap hasil feedback

\begin{tabular}{|c|c|c|c|c|}
\hline \multirow[b]{2}{*}{ Penilaian Terhadap Kegiatan } & \multicolumn{4}{|c|}{ Jumlah Faktor Yang Dipentingkan } \\
\hline & $\begin{array}{l}\text { Sangat tdk } \\
\text { setuju }\end{array}$ & $\begin{array}{l}\text { Tidak } \\
\text { setuju }\end{array}$ & Setuju & $\begin{array}{l}\text { Sangat } \\
\text { setuju }\end{array}$ \\
\hline $\begin{array}{l}\text { 1. Kegiatan ini sudah sesuai dengan } \\
\text { tujuan kegiatan itu sendiri. }\end{array}$ & & & 12 & 10 \\
\hline $\begin{array}{l}\text { 2. Kegiatan ini sudah sesuai dengan } \\
\text { kebutuhan masyarakat sasarnya. }\end{array}$ & & & 13 & 9 \\
\hline $\begin{array}{l}\text { 3. Waktu pelaksanaan kegiatan ini relatif } \\
\text { telah mencukupi sesuai kebutuhan. }\end{array}$ & & 2 & 12 & 8 \\
\hline $\begin{array}{l}\text { Telkom bersikap ramah, cepat dan } \\
\text { tanggap membantu selama kegiatan. }\end{array}$ & & & 13 & 9 \\
\hline $\begin{array}{l}\text { 5. Masyarakat setempat menerima dan } \\
\text { mengharapkan kegiatan Universitas } \\
\text { Telkom saat ini dan masa yang akan } \\
\text { datang. }\end{array}$ & & 2 & 11 & 9 \\
\hline Jumlah & 0 & 4 & 61 & 42 \\
\hline $\begin{array}{l}\% \text { (Jml masing-masing : total) } \\
\text { Jumlah \% setuju+sangat }\end{array}$ & 0 & $4 \%$ & $\begin{array}{l}57 \% \\
96 \%\end{array}$ & $39 \%$ \\
\hline
\end{tabular}

Berdasarkan tabel evaluasi kegiatan tersebut, pelatihan dan program pengabdian masyarakat dengan guru SMP Bina Taruna sebagai mitra sasar ini dinilai sangat baik, yaitu jumlah setuju dan sangat setuju mencapai angka lebih dari $80 \%$, dengan jumlah $96 \%$. Sasaran hasil yang ingin dicapai oleh program abdimas ini adalah sebagai berikut:

1. Meningkatkan kemampuan para pengajar dalam menggunakan media alternatif dalam pembelajaran daring

2. Meningkatkan efektifitas pembelajaran daring dengan menggunakan konferensi video interaktif

Evaluasi pelaksanaan program dengan membagikan wawasan mengenai konferensi interaktif yang kami paparkan untuk diteruskan kepada guru. Partisipan kegiatan ini merupakan para guru dengan harapan dapat membantu pengembangan pengajaran secara daring yang lebih efektif secara dua arah antar guru dan siswanya. Dokumentasi kegiatan ini dapat diakses pada laman (Syafikarani et al., 2021) berikut, https://youtu.be/40xiwrOShH4. 


\section{KESIMPULAN}

Evaluasi pelaksanaan program melalui kegiatan pengabdian yang dilakukan ini dinilai membantu pengembangan pengajaran via daring dengan aplikasi konferensi interaktif yang lebih efektif. Hal ini disimpulkan dari hasil kuesioner sebagai berikut:

1. $96 \%$ dari jumlah responden pelatihan yang telah diadakan memberikan feedback positif bahwa kegiatan ini sesuai dengan kebutuhan partisipan kegiatan pelatihan guru SMP Bina Taruna.

2. Guru-guru SMP Bina Taruna mengharapkan adanya program kegiatan pelatihan berkelanjutan yang dapat menambah wawasan para guru dalam era digital ini.

\section{UCAPAN TERIMA KASIH}

Tim mengucapkan terima kasih kepada Bapak Sutisna, selaku Kepala SMP Bina Taruna dan Bapak Tatang sebagai perwakilan dari Bapak Ibu guru SMP Bina Taruna dalam membantu persiapan dan kegiatan pengabdian pada masyarakat.

\section{DAFTAR PUSTAKA}

Aulia, R., Syafikarani, A., \& Supriadi, O. A. (2021). Menunjang Pembelajaran Daring , Guru Smp Bina Taruna. 04(01), 53-60.

Eddy, E., Usman, A., \& Dafitri, H. (2021). Pelatihan Penggunaan Aplikasi Pembelajaran Daring Untuk Mengoptimalkan Peran Guru Pada Pembelajaran Jarak Jauh (PJJ). Jurnal Pengabdian Masyarakat: Darma Bakti Teuku Umar. https://doi.org/10.35308/baktiku.v2i2.2495

Joshi, A., Kale, S., Chandel, S., \& Pal, D. (2015). Likert Scale: Explored and Explained. British Journal of Applied Science \& Technology. https://doi.org/10.9734/bjast/2015/14975

Kemendikbud. (2020). Sajian Pembelajaran Daring Bersama Duta Rumah Belajar. Www.Kemendikbud.Go.Id.

Miarso, Y. (2011). Menyemai Benih Teknologi Pendidikan. In Computer.

Rosali, E. S. (2020). Aktifitas Pembelajaran Daring Pada Masa Pandemi Covid -19 Di. Geography Science Education Journal (GEOSEE).

Sadikin, A., \& Hamidah, A. (2020). Pembelajaran Daring di Tengah Wabah Covid-19. BIODIK. https://doi.org/10.22437/bio.v6i2.9759

Sumarlin, R. (2021). Pelatihan UI Dan UX Aplikasi Berbasis Web Dalam Menunjang. 04(02), 2-8.

Syafikarani, A., Supriadi, O. A., \& Aulia, R. (2021). Abdimas 2021 - SMP Bina Taruna. Youtube. https://youtu.be/40xiwrOShH4

Tampubolon, B., Christanto, L. M. H., Anasi, P. T., \& Adlika, N. M. (2021). Pelatihan Pembelajaran Daring Pada Guru-Guru Geografi di Kabupaten Kubu Raya. Dedication: Jurnal Pengabdian Masyarakat.

Tuti, F. M., Musriandi Riki, \& Suryani Linda. (2020). Covid-19 : Penerapan Pembelajaran Daring Di. Dedikasi Pendidikan. 